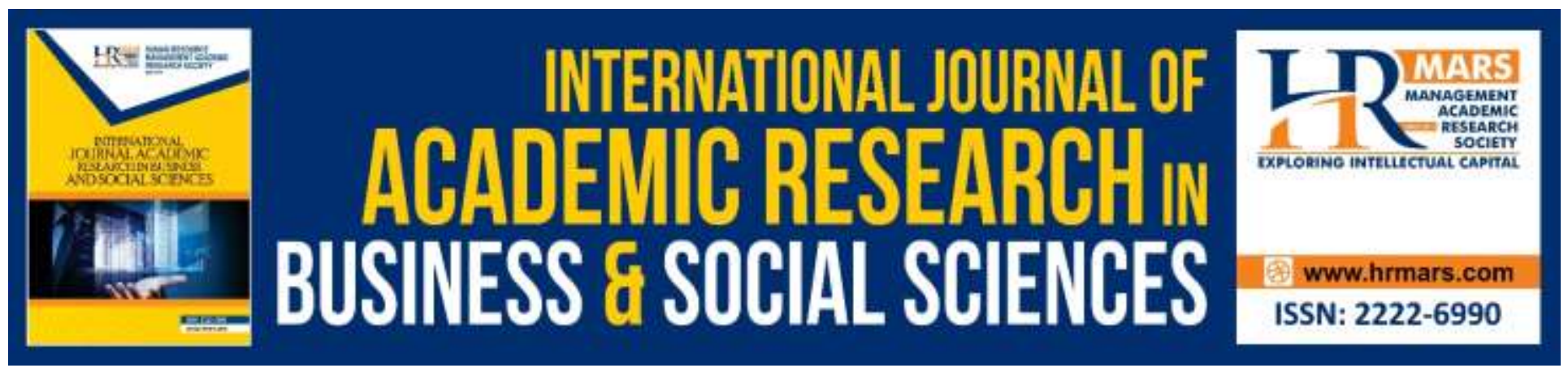

\title{
Are you Receiving Complaints Regarding Processing Time Response? The Suitable Management Structure for Expanding Oil and Gas Contractor in Malaysia
}

\author{
Md Jazli Bin Md Johari
}

To Link this Article: http://dx.doi.org/10.6007/IJARBSS/v9-i7/6159

DOI: $10.6007 /$ IJARBSS/v9-i7/6159

Received: 06 May 2019, Revised: 19 June 2019, Accepted: 01 July 2019

Published Online: 23 July 2019

In-Text Citation: (Johari, 2019)

To Cite this Article: Johari, M. J. B. M. (2019). Are you Receiving Complaints Regarding Processing Time Response? The Suitable Management Structure for Expanding Oil and Gas Contractor in Malaysia. International Journal of Academic Research in Business and Social Sciences, 9(7), 670-685.

Copyright: (C) 2019 The Author(s)

Published by Human Resource Management Academic Research Society (www.hrmars.com)

This article is published under the Creative Commons Attribution (CC BY 4.0) license. Anyone may reproduce, distribute, translate and create derivative works of this article (for both commercial and non-commercial purposes), subject to full attribution to the original publication and authors. The full terms of this license may be seen

at: $\underline{\text { http://creativecommons.org/licences/by/4.0/legalcode }}$

Vol. 9, No. 7, 2019, Pg. 670 - 685

http://hrmars.com/index.php/pages/detail/IJARBSS

JOURNAL HOMEPAGE

Full Terms \& Conditions of access and use can be found at http://hrmars.com/index.php/pages/detail/publication-ethics 


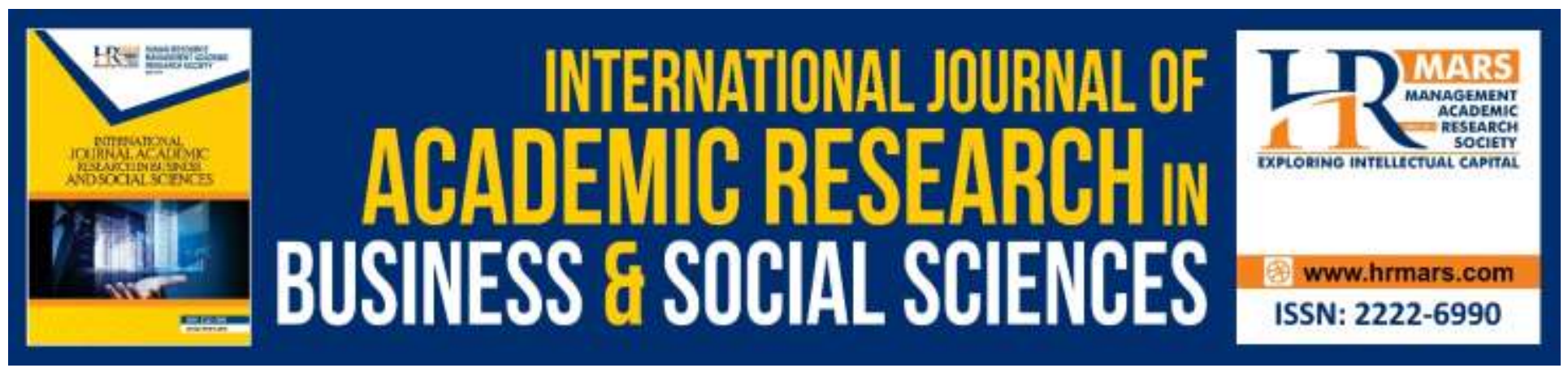

\title{
Are you Receiving Complaints Regarding Processing Time Response? The Suitable Management Structure for Expanding Oil and Gas Contractor in Malaysia
}

\author{
Md Jazli Bin Md Johari \\ Azman Hashim International Business School, Universiti Teknologi Malaysia, 81310 Johor Bahru, \\ Johor, Malaysia \\ Email:mjazli2@gmail.com
}

\begin{abstract}
Nowadays, oil and gas companies are competing each other because whichever company that able to provide immediate response and mobilized faster, they will be the winner. Lack of sensitivity in managing and monitoring processing time for certain process or procedures are bad for continuous business growth. This problem occurs because of poor management structure that applied by the organization especially for a company having parent-subsidiaries company. Thus, this paper is to highlight the importance of management structure for organization. Eventually, this paper compares the most suitable structure between centralized and matrix structure management approach in order to implement in Malaysia's expanding oil and Gas Company. Based on the literature review had been reviewed, theories that explained about managing in an organization is contingency theory which can define "the best way of organizing depends on the environment the organization operates in" (Scott, 2004). On the other hand system theory explained on the "of abstract social communication systems conceptualizes social structures and organizations as systems of inter-human communications." (Ott and Shafritz, 1996). According to (Kuprenas, 2003a) system theory is a traditional hierarchy overlaid by some form of lateral authority, influence, or communication. Conversely, centralize management is the organizational structure that provides authority to the company (Maleki, 2014) and matrix management is designed based on the functional and project organization (Larson and Gobeli, 1987). By assuming operation of organization depending to communication within the internal and external parties in the organization, thus time response which took for communication would be the benchmark in proposing the suitable management structure. This paper focus to investigate the behavior of centralized and matrix structure management which has been implemented in oil and gas companies in Malaysia with condition it is a 'mother - daughter' company. Furthermore, this study to give the best picture especially mother company organization to determine the best organization structure to be implement. The right selection will drive organization to improve and increase the level of communication, operation and business opportunities between internal and
\end{abstract}


INTERNATIONAL JOURNAL OF ACADEMIC RESEARCH IN BUSINESS AND SOCIAL SCIENCES Vol. 9, No. 7, July, 2019, E-ISSN: 2222-6990 @ 2019 HRMARS

external parties of organization. This may help to improve the business operation between internal and external parties within the organization which always faced problem and difficulties in communication among staff, vendor and client.

Keywords: Centralize Organization Structure, Matrix Organization Structure, Internal Communication, External Communication, Time Response, Expanding Oil and Gas Company, Malaysia

\section{Introduction}

In Malaysia, a number of the smaller company usually under an established company to allow them to stay longer on the market by expanding their business operations in order to maintain sustainability of the company as they were facing many other competitors especially in oil and gas sector (Kim and Mauborgne 2005). An established company was represented as the parent company and owns its subsidiaries from the smaller companies where the parent companies, mostly own the majority shareholders. Mainly, the subsidiaries were controlled by its parent companies that possessed a certain level of autonomy. The level of autonomy was depended from the factor of subsidiary competences, corporate embeddedness and local embeddedness(Simoes 2006) which reflected into the decision-making of both parties. The autonomy level of a parent company over its subsidiaries preserved to be higher or lower(Simoes, 2006).

When dealing with the subsidiaries competences, subsidiaries that have bigger market scope have a tendency to have higher autonomy as lacked of having a wide scope of market orientation, it would create dependence towards the parent company which reduced the control over the company(Taggart and Neil, 1999). The level control of decision-making will be increased when the subsidiaries were able to manufacture specific or unique product that imaged the subsidiaries identity(Taggart and Neil 1999). In terms of corporate embeddedness, it relied on the company goals, meaning that if the parent company was getting involved or taking control most of its affiliate management, thus the subsidiaries were likely to have lower level of autonomy since frequent rotation of managers was required(Simoes, 2006). However, autonomy within subsidiaries would be increased if the subsidiaries had influenced on local embededdness (Simoes, 2006).

Nevertheless, past research had demonstrated that higher autonomy occurred in the human resources but least for finance decision(Hedlund 1984). The parent company had a tendency to control the human resources management (HRM) practices so that HRM implementation could be standardized towards its subsidiaries(Wilhelm, 2013; Wright and Mechling, 2002). Besides, specific human resources management could be controlled in term of recruitment and the selection of the higher-level managers(Mahmood, 2010). As the HRM was being controlled by the parent company, different company implemented different ways of management in order to achieve the company's goals. Several of the parent companies required its subsidiaries to direct reporting to the top-level management, but some of it allowed the subsidiaries to have their own decision making so they could accelerate the process of the tasks given(Montana and Charnov, 1993). Nonetheless, in order the subsidiaries to have controlled by its owner, interdependence needed to be reduced towards its parent - make it passive. company(Simoes, 2006).

The research study should be able to answer to the following research questions: (1) How to determine the best organizational structure to be used in an organization? (2) What type of organization structure; centralized or matrix structure is the most suitable for expanding the 
organizational? (3) How effective the communication between internal and external party? Numerous numbers of researches have been performed regarding the management structure where the studies described the importance on selecting the precise management structure before implementing in the organizations. Specific investigation to the structure management in determining the most effective management to be implemented in the organization will improve the organizations to sustain and maintain the business over its competitor(Mahmood 2010; Montana and Charnov, 1993).

Even though it was challenging to have error-free in the management system, but the information that has been analyzed and evaluated by the past researchers could be utilized to improve the present system management. The most effective management structure could be determined through the studies and adopted in the organizations, especially in the parentsubsidiaries (Hedlund, 1984)company as they were dealing with many stages of management that involved from lower, intermediate and upper level of management. Different management levels in the organization have a tendency to make mistakes that could affect the company(Kuprenas, 2003b). From the study, the researcher presumes to provide: 1) an understanding of the importance of the management structure and how it works in a company, especially for the parent-subsidiaries companies 2) a studied that able to identify related concepts that linked between parent-subsidiaries and overall company performance 3) outcomes to help the companies in deciding the most effective and suitable management besides improving the internal problem in management.

Yet, how well can both managements structure; centralized and matrix management offers neither smooth management structure nor improvise time-response of decision making?

However, it not known how well can both managements structure; centralized and matrix management offers neither smooth management structure nor improvise time-response of decision making? It is because centralized management and matrix management has its pros and contrast depends on the company desires to select which the most effective to implement in their whole organizations.

Basically, this study is twofold. First chapter will discuss the main idea and provides overviews on the relationship of the parent - subsidiary company, the concepts of management structure, pronounced the objectives of the study, problem statements, and significance of study and limitation of the study. Second chapter provides the literatures related to the research topics, theoretically and empirically as well as discuss it in sub-chapter on the management structure, centralized, matrix management, and the relationship between personnel, upper level management, and its clients in term of communication.

\section{Problem Statement}

Despite of all the management structure had been introduced by the past researchers, the companies still searched the best method to implement those methods in the organizations. Some of the structured management revealed the imperfection of the management structure, as there were disadvantages on the contrary of its advantages. Montana, 1993, had described that they were several of methods that could be implied in an organization to achieve the company's mission and vision (Montana \& Charnov, 1993). 
Montana, 1993, agreed that the effective management structure to be implemented in the organization by departmentalization where each discipline was reported to the head of department (Montana \& Charnov, 1993). However, Montana, 1993, stated that eight methods in departmentalization, which, distinguished by function, process, product, market, customer, geographic area, matrix organization and combination approached (Montana \& Charnov, 1993). However, the management structure is not limited to departmentalization, many more structured management had been introduced which caused difficulties to the company in selecting the best management structure (Montana \& Charnov, 1993).

On the other hand, Steensen, (2014), stated that the organizational strategy was important to develop a systematic strategy in a company (Steensen, 2014). Steensen, (2014) addressed out, management structure, organization studies, and strategic management would influence company's systematic strategy (Steensen, 2014). However, he had agreed that the framework had only been incapable to determine the relation of the strategy (Steensen, 2014). Failed to decide appropriate methods would lead to chaos in managing the company (Steensen, 2014). The reason is at the earliest stages to set up a company, the founder of the company required to study all the possibilities of the management structure that would give the highest benefit towards the company.

To ensure the market sustainability of the company, especially the company who had a relationship of the mother - daughter company, it was important to develop the systematic and strategic management structure to obtain the excellent end results. Most of the subsidiaries were dictated by their parent company where last decision-making was controlled by its parent companies (Steensen, 2014). This situation became worse when the subsidiaries were unable to reduce interdependence through its parent company which leading higher level of autonomy towards the parent company. Lack of efforts to reduce interdependency towards the parent company and insufficient knowledge to run the company were the causes that lead a subsidiary to lost control over her company (Steensen, 2014) (Taggart \& Neil, 1999).

As the parent company, most of them would implement centralized management because the parent company was able to monitor the overall of its subsidiary's activities. On the other hand, implementation of centralized management would lead to miss-communication as they had practiced one-way communication. On the contrast, its subsidiaries would refer to implement the matrix management because the subsidiaries could have control over its company to make their own decision without referring to upper level management or the parent company. This type of management adopted a two-way communication, thus communication and knowledge transfer towards the lower level management could be improved. If the conflicts occurred, the performance of the company will reduce that lead to have ineffective management over the overall organizations.

\section{Management Structure}

An organization needs a structured management to control the entire company's affair so that the vision and mission of a company can be achieved. Structured management can be divided into several methods, including departmentalization, delegation, scalar principle, centralization, decentralization and contingency approach(Montana and Charnov, 1993).

Company especially in oil and gas sector, including the parent and its subsidiaries should have their own implementation of the management in order to have an excellent management system. 
There are concepts of management structure that all companies to follow after they established their own vision and mission(Montana and Charnov, 1993). Montana (1993) publicized that several organizations structures, including departmentalization, delegation, scalar principle, centralization, decentralization and contingency approach could be implemented in a company either one of them or combined several of the management structures(Montana and Charnov, 1993). Despite of all the management structure had been introduced by the past researchers, the companies still searched the best method to implement those methods in the organizations. Some of the structured management revealed the imperfection of the management structure, as there were disadvantages on the contrary of its advantages. Montana, 1993, had described that they were several of methods that could be implied in an organization to achieve the company's mission and vision(Montana and Charnov, 1993).

Montana, 1993, agreed that the effective management structure to be implemented in the organization by departmentalization where each discipline was reported to the head of department(Montana and Charnov 1993). However, Montana, 1993, stated that eight methods in departmentalization, which, distinguished by function, process, product, market, customer, geographic area, matrix organization and combination approached(Montana and Charnov 1993). However, the management structure is not limited to departmentalization, many more structured management had been introduced which caused difficulties to the company in selecting the best management structure(Montana and Charnov, 1993).

On the other hand, Steensen (2014), stated that the organizational strategy was important to develop a systematic strategy in a company(Steensen, 2014). Steensen (2014) addressed out, management structure, organization studies, and strategic management would influence company's systematic strategy(Steensen, 2014). However, he had agreed that the framework had only been incapable to determine the relation of the strategy(Steensen, 2014). Failed to decide appropriate methods would lead to chaos in managing the company(Steensen, 2014). The reason is at the earliest stages to set up a company, the founder of the company required to study all the possibilities of the management structure that would give the highest benefit towards the company.

Departmentalization can be defined as a group of functions that have been specifically managing units in the organization that occupied in the dissection of labor(Montana and Charnov 1993). Montana, (1993) claims that this method is the most effective way to achieve company's goals(Montana and Charnov, 1993). Departmentalization can be segregated in different techniques of function, process, product, market, customer, geographic area, matrix or project organization and combination approach(Montana and Charnov, 1993). Departmentalization allows to have a president as the highest key personnel and follows by top level managers that will responsible for each task given by the president.

Structured management can also be achieved by delegation methods. Delegation is needed when the working situation becomes complicated and the need to hire other employees to complete the tasks. Employees have their own authority and responsibility to accomplish the task given by his superior(Montana and Charnov, 1993). On the contrast, if the manager unable to control the situation, there will be loss of control, reverse delegation and loss of job(Montana and Charnov 1993). It also involve with scalar principle, which apply concepts of chain of command(Feforciow, 2014). 
Centralization and decentralization, both are acting in the opposite ways. Centralized management usually has limited authority at the lower level in the company. On the contrary, decentralized management allows lower levels of management to have larger authority to make decisions. Montana argued that, centralized and decentralized management could not classify as an effective way to manage an organization(Montana and Charnov, 1993). Both have advantages and disadvantages that need to bear with. As for centralized management is implied into management of a company, mostly they have uniformity in terms of systems, practices and performance and business guidelines. On the other hand, decentralization also offers faster decision making because every decision isn't going to the top-level management to make a decision(Montana and Charnov, 1993).

\section{Centralization Management Structure towards Company}

Centralization will make the decision-making is made by the command hierarchy where the more centralized the structure the fewer decision will be made by the lower level of staff(Maleki, 2014). To ensure the market sustainability of the company, especially the company who had a relationship of the mother - daughter company, it was important to develop the systematic and strategic management structure to obtain the excellent end results. Most of the subsidiaries were dictated by their parent company where last decision-making was controlled by its parent companies(Steensen 2014). This situation became worse when the subsidiaries were unable to reduce interdependence through its parent company which leading higher level of autonomy towards the parent company. Lack of efforts to reduce interdependency towards the parent company and insufficient knowledge to run the company were the causes that lead a subsidiary to lost control over her company(Steensen 2014; Taggart and Neil, 1999).

As the parent company, most of them would implement centralized management because the parent company was able to monitor the overall of its subsidiary's activities. On the other hand, implementation of centralized management would lead to miss-communication as they had practiced one-way communication. On the contrast, its subsidiaries would refer to implement the matrix management because the subsidiaries could have control over its company to make their own decision without referring to upper level management or the parent company. This type of management adopted a two-way communication, thus communication and knowledge transfer towards the lower level management could be improved. If the conflicts occurred, the performance of the company will reduce that lead to have ineffective management over the overall organizations.

Generally, the subsidiary would refer most of decision to the parent company and waited for some period to get approval from the upper level management. It was impossible to get fast approval from upper level management even for urgent issues. The main objective of this paper to identify the most suitable management method to be implemented in the organizations, especially in companies that attached with its parent company(Simoes, 2006). Past researched had revealed that there were several of management structure that could have implemented in an organization(Montana and Charnov, 1993). The different type of structural management would arise a conflict between a mother - daughter company (Steensen, 2014) which involved in overall company's performance and difficult to reach the company's targets.

The adoption of an accurate management structure will give high impact to the organizations where the positive impact towards the company is in demand. It is crucial to analyze thoroughly the 
appropriate management structure to reduce the risk while managing the organizations $(\mathrm{O}$ and $\mathrm{H}$ 2015; Tohidi, 2011). It has been known that all the management structure had pros and contrasts. Thus, the contradictions need to evaluate in detail so the characteristics of each management structure method can be recognized and to be implemented in the organization(Kuprenas, 2003b; Montana and Charnov 1993). The objectives of the study are as follows: (1) To recognize and investigate the management structure of an organization for comparable purposes. (2) To evaluate the most suitable structure management; centralized management and matrix management characteristic in order to implement in the organization. Figure 1 shows the scope of authority for centralized management. Feizi, 2008 though his study on "A survey on the relationship between organizational structure and organizational creativity: a case study of Shiraz high schools" claims that the more complex the structure of a company, the higher the centralization of a company, it will reduce the creativity of the company. The study is based on the survey done in a case study to investigate the relationship between organizational structure and its creativity(Feizi, 2008).

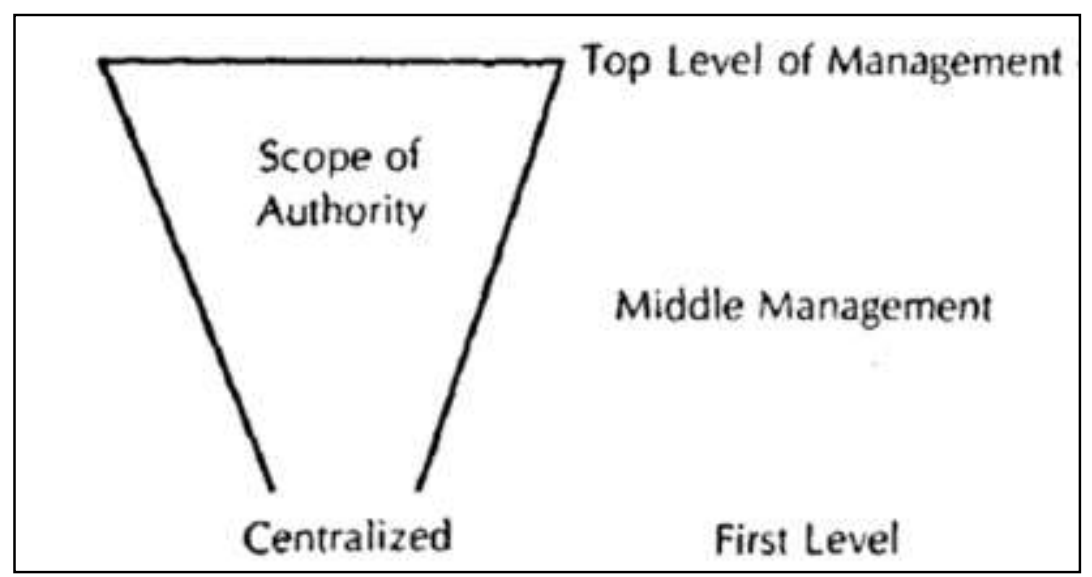

Figure 1: Scope of Authority for Centralized Management(Montana and Charnov, 1993)

Bon, (2013), carried out a study on the "Impact of Total Quality Management on Innovation in Service Organizations: Literature review and New Conceptual Framework". The results described that innovation or creativity that contributes to an idea which is important to the organization because through innovation will generate new ideas to produce competitive products in order to sustain in the market(Bon, 2013). However, creativity or innovation is giving the negative impact of centralized management because centralized management not encouraged personnel to contribute on their own ideas towards the company(Brown and Lamming 2005; Maleki, 2014).

On the other hand, the result done by Bhargava and Kelkar (2011), shows a positive relationship between centralization and human resource in job hiring. It means that through centralization implication towards the company, it will influence more in the human resource management structures in order to recruit personnel(Bhargava and Kelkar, 2011). However, it will dictate from the management of the parent company since higher autonomy in human resource management from them(Simoes, 2006).

Maleki, 2014 explains that in centralized organization not much different with the chain of commands, where lower level staff is awaiting instructions from his manager in order to complete the tasks(Maleki, 2014; Montana and Charnov, 1993). This condition will create issues of self- 
confidence and self-motivated in each lower rank personnel where most of the personnel that waiting instructions from their superior unable to think critically(Maleki, 2014). They dependent with their manager's decision as are not able to make decisions of their own. Thus the capabilities to buildup lower rank of staffs' self-motivated, self- contained, self- discipline and etc would reduce(Maleki, 2014).

On the other hand, in the survey of "Nurse Leaders; Current and Future Management of Contingent Workforce Operations" it's starting to implement centralized organization as they have estimated that an increasing of management efficiencies. Purpose shifted organizational structure to centralized management because of to improve staffing working hours and operation(Haselwander, 2014).

In the report stated in Morning Star, the organization shifted the organization structure to centralized management and made a few changes to adapt with new management structured. They claim that changing the management into a centralized management that able to help the company become more sturdy and robust for future growth(Mansueto, 2013). However, in the beginning of the changes, they spend a million money to restructure its management by having the cost of compensation towards the company(Mansueto, 2013).

Taking example from annual report for Technip, 2012, Technip implement centralized management that focus on the cash management by Technip's headquarters and synchronized by all finance departments of the subsidiaries. As the cash pooling has been centralized, an agreement with Technip's subsidiaries has been signed off in order to secure surplus cash throughout the company(Pilenko, 2012). From the annual report, Technip centralized its management only for their financial department for full monitoring of its subsidiaries cash flow.

Ernst and Young explain that embedded a centralized operating modeled to the organization can save the cost of the whole process of the company. Concepts of centralized operating model is having integration of different services but sharing the same drivers. The benefits of having centralized operating management to enhance process efficiency, uniformity and career opportunities and reduction of the operation cost from 30 percent to 50 percent. Furthermore, centralized management can ensure the company's strategic, operational, financial, or risk are manageable and can be operated globally. The centralized management also able to describe the risk owners that accountable to the person involved(2014).

Ernst and Young suggest that most of the companies should practice centralized management to minimize cost and reduce management risk. However, the companies shall confront with the advantages and disadvantages of the centralized management in order to adopt in the company's management. The advantages of the centralized management, the productivity will improve and increases by having a new operating centre and able to boost up production activities. Business acceptance among the others is higher as practicing existing procedures. On the contrast, companies will deal with complexity due to the procedures and different practices among department or other region(2014).

\section{Implementation of a Matrix Organization Structure towards the Company}

The matrix is derived from the conventional functional organization to project organization. Functional organization is getting info from engineering, research, accounting and administration. On 
the other hand, project organization is set up as an individual project and lead by a project manager(Larson and Gobeli 1987).

Matrix organization is the combinations of two separate departments become one department, which everything will be reported to the functional manager and project manager. Matrix management has a different point of forms that can be divided into three including functional matrix, balanced matrix and project matrix(Kuprenas 2003b; Larson and Gobeli 1987). Each matrix organization can be differentiated through the team leader responsibilities of each department. An Example of the matrix chart can be referred in Figure 2.

Primarily, a functional matrix happens when a functional manager is accountable for designing and technical of the overall project. Apparently, the project manager is just assisting indirectly to the functional manager to expedite and monitor the project to accomplish. In contrast, a project matrix works as the other way around when the functional manager has limited authority to advise and provide technical consultation in order to complete the project. Whereas, a project managers have the responsibilities to foresee the project completion and have direct authority to decide about the staffs and working flow. In contrast to balanced matrix, both of the key personnel; functional manager and project manager share the same accountabilities where each of them identifies the requirement and thinking the means to complete the project respectively(Kuprenas 2003b; Larson and Gobeli 1987) 
INTERNATIONAL JOURNAL OF ACADEMIC RESEARCH IN BUSINESS AND SOCIAL SCIENCES Vol. 9, No. 7, July, 2019, E-ISSN: 2222-6990 @ 2019 HRMARS

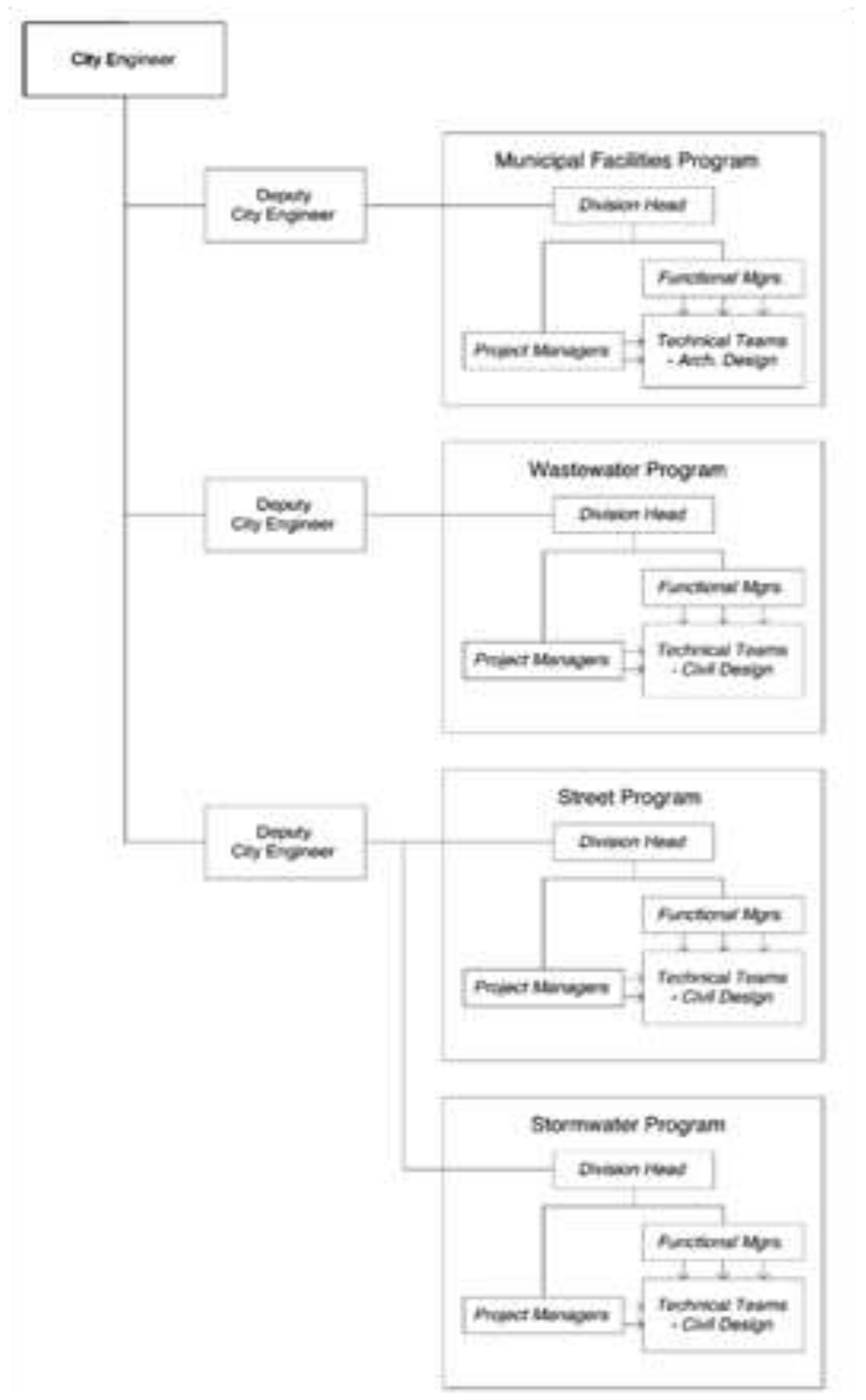

Figure 2: Example of Matrix Management Organization Chart 
The companies require implementing the matrix management when the condition of business required having extremely responsive of two sections in parallel time and the companies dealing with unpredictability issues that involve very high information processing. If there are companies in human resources or financial constraint, matrix structure aid to provide stability and flexibility in decision making(Davis and Lawrence, 1978). Matrix organization able to combine efficiency and effectiveness in order to maximize performance of the company by having both functional and project forms in one organization(Janićijević and Aleksić, 2007).

Larson, 2008 has carried out a study regarding to the implementation of the matrix organization in Canada and US. The study revealed that matrix management is widely used, where the project matrix is the most popular compared to balanced and functional matrix(Larson and Gobeli, 1987). The study also states that project matrix is the most effective matrix management, whereas functional matrix was reported as the least effective matrix project. Specific parameters have taken into account in order to measure the rate of the effectiveness of the matrix organization(Larson and Gobeli, 1987).

By implementing matrix organization in the company, the matrixes; (functional, balanced and project matrix) allow to obligate the resources to the maximum responsibilities. At the same time project manager shall have further control of his task, which will increase the project integration among the other employees. Furthermore, the matrixes will enhance the information flow both laterally and vertically as the communication given from the top management. Decision can be made from different departments since having frequent contact among the team-members. The experts and specialist in such discipline that involved in multidisciplinary projects allow to remain in the existing discipline when the job is completed, which will maintain as an expert in each discipline(Kuprenas, 2003b; Larson and Gobeli, 1987).

However, there is an argument states that matrix management can lead to anarchy once the project manager and functional manager lost control of the management. Less experienced in practicing the matrix management will cause confusion among the leaders and staff. The problem occurs when the project is behind schedule and project manager lost control over his projects. The inexperienced leaders will lead to disaster, especially failing in financial systems, distressed inventories and huge debts when he underestimates future market (Davis and Lawrence, 1978).

Project and functional managers will struggle for since the matrix management is a dual command which conflict occurs on both parties due to overlap responsibilities. Davis suggests that in order to prevent for the imbalance power, matrix organization should not be implemented. During economic recessions, the matrix organizations are the primary poorest management, especially for new companies that have weak management. Slow response, lack of action from the top level management lead, project or functional manager unable to plan a contingency approach to overcome the problem during recession time(Larson and Gobeli, 1987) (Davis and Lawrence, 1978).

Kuprenas, (2003), in his studies on "Implementation and performance of a matrix organization structure" reveals that there are difficulties that associates with the matrix organization. Kuprenas, (2003), claims that performance under matrix organization difficult to measure due to the many uncertainties that need to include in the research. In order to implement the matrix organization, several factors has been detailed out to overcome improve matrix organization. To overcome confusion over roles and responsibilities, summary lists of roles and responsibilities for each 
functional and project managers has been created. The reporting system over the department has been improved by crating project design template for every project. A project protocol has been developed in order to overcome project delays or changes. All staffs have been trained in human resource in order to prevent bad influences since strong communication skills and ability working as a team have become a requirement of the matrix organization(Kuprenas, 2003b).

\section{Decision-Making in an Organization}

This research focus on decision making as well as communication in lower level to top level management and organization. Currently, most of the personnel from lower level of management facing difficulty to report to the upper level management. The reporting had to go through several stages before it could get through the upper level management(Simoes, 2006). Andrew, (1986) suggest that by creating groups of work in an organization was able to minimize the internal conflict in the company(Andrew, 1986). Leader would be chosen to drive the group achieving their target where leader was the representatives to upper level so that all reports on every task that have been done could directly informed to the higher level. Thus, without the intervention of leadership, it was difficult to communicate directly to upper management. This flow of work might take a longer time to accomplish a project because slow feedback from management. As a general, below conceptual framework represented overall view of centralize and matrix structure suitability in the expanding oil and gas contractor organization.

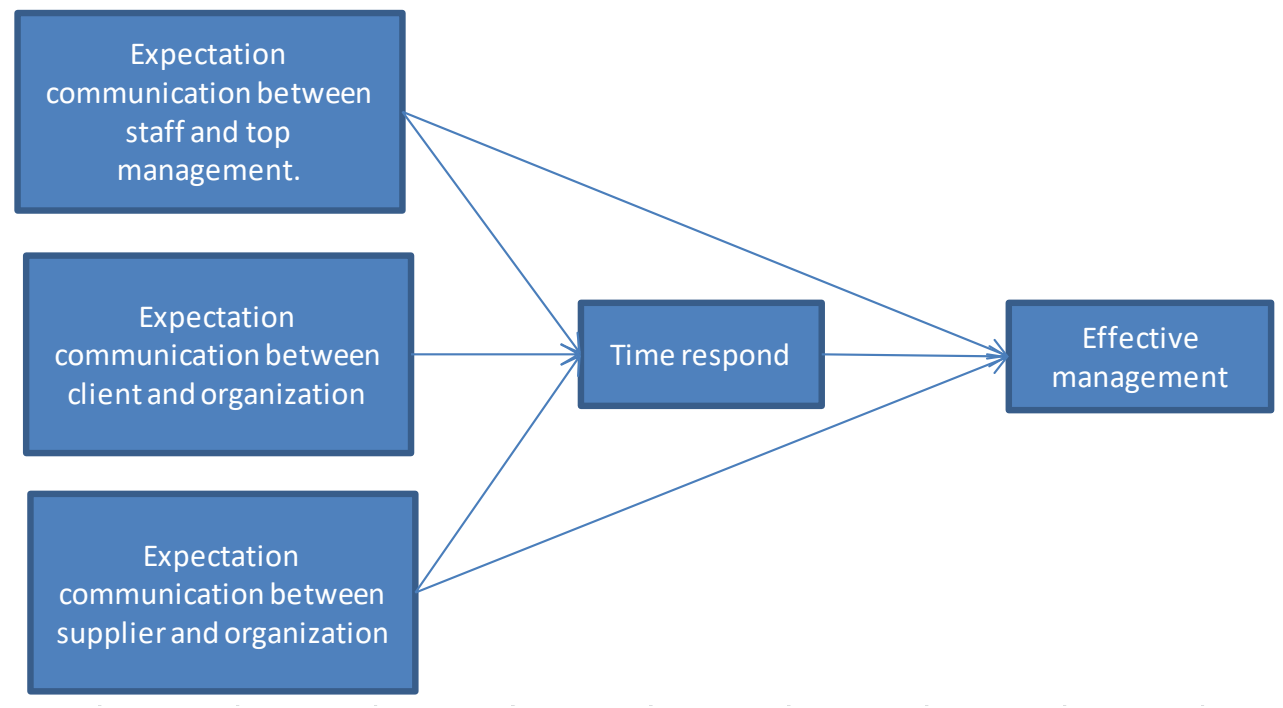

Figure 3: Conceptual framework for research study.

\section{Expectation and Communication between Staff and Top Management}

Centralized management allows a limited amount of authority which is assigned to the organization. Scope of authority is reduced from the top-level management to the lowest level management. In this condition, any decision making will be approved by the top-level management, which will through several department or level management before reach to the top level. On the other hand, matrix management segregates various into various departments or division and each division will 
INTERNATIONAL JOURNAL OF ACADEMIC RESEARCH IN BUSINESS AND SOCIAL SCIENCES

Vol. 9, No. 7, July, 2019, E-ISSN: 2222-6990 ¿C 2019 HRMARS

be managed by project managers and functional managers. Both managers have the authority to allow decision making without referring to top level management.

\section{Expectation and Communication Between Client and Organization}

Generally, client will liaise with the organization which has direct communication with the personnel that responsible for the projects. For instant, Client A will lose to all personnel in a different division, which is a direct communication to the organization. However, if centralized management is implied in the organization, every decision must go through the top level of management then the information will pass to client A through the personnel at lower level management. In contrast with matrix organization, Client $A$ able to receive a response directly from the appointed project manager to handle the projects.

\section{Expectation and Communication between Supplier and Organization}

In this context, supplier has become one of the essential parties that will continue the project until it is completed. Most of the supplier will deal with the discipline engineers before procuring the equipment. However, the end decision depends on the top level management. As for centralized management, purchase order only can be finalized after approval from the director. Same goes to the matrix management since it involves with cash flow out, top level management will dictate the type of equipment purchased based on the given budget.

\section{Conclusion}

Major findings in this research that decision making while implementing management matrix is more effective than the centralized management. It is because several decision do not required through the upper management and it can be decided straight to the person-in-charge even though the key personnel from the lower level management. However, it is important that, before the selection of the key personnel from lower level to the upper level management, the person-in-charge shall be a competent person that's able to learn faster, have the critical thinking and they can understand the needs of the project or company.

Conversely, the centralized management will have a longer response time. For example, the pattern of the company of oil and gas in Malaysia, some of them are the subsidiaries of a multinational parent company (MNC). For sure, if any inquiries towards the subsidiary company in Malaysia cannot simply make a decision and required to wait for the parent company's decision which is from their upper level management.

\section{References}

Andrew, H. (1986). Central Problems in the Management of Innovation. Management Science , 32 (5).

Bhargava, S., \& Kelkar, A. (2011). Examining the relationship between organizational structure, job involvement, job satisfaction, and empowerment: Implications for human resource development. International Journal of Human Resources Development and Management, , 150-161. 
INTERNATIONAL JOURNAL OF ACADEMIC RESEARCH IN BUSINESS AND SOCIAL SCIENCES

Vol. 9, No. 7, July, 2019, E-ISSN: 2222-6990 @ 2019 HRMARS

Bon, A. T. (2013). Impact of Total Quality Management on Innovation in Service Organizations: Literature review and New Conceptual Framework. Procedia Engineering , 516-529.

Brown, S., \& Lamming, R. (2005). Innovations- Managing the Renewal Business. Strategic Operations Management, $140-184$.

Davis, S., \& Lawrence, P. (1978, May). HBR.org. Retrieved from Harvard Business Revie: https://hbr.org/1978/05/problems-of-matrix-organizations

EYGM. (2014). Centralized Operations; The Future of Operating Models for Risk, Control and Compliance Functions. UK: Earnst \& Young Global Limited.

Feforciow, L. (2014). Strategies for the Management and Adoption of Impact Capture Processes within Research Information Management Systems. Procedia Computer Science , 25-32.

Feizi, M. (2008). An Analyzing Survey on the Relationship between Organizational Structure \& Organizational Creativity Case Studies: Shiraz Middle School Proceedings of the 2nd Conference on Creation Recognition \& Engineering of Innovation Management in Iran Tehran. Science Research Institute Creativity and Innovation.

Haselwander, N. (2014). Survey of Nurse Leaders; Current and future management of contingent workforce operations. US: Shift Wise.

Hedlund, G. (1984). Organization in-between: The evolution of the mother-daughter structure of managing foreign subsidiaries in Swedish MNCs. Journal of International Business Studies , 109-123.

Janićijević, N., \& Aleksić, A. (2007). Complexity of Matrix Organization and Problems Caused by its Inadequate Implementation. Ekonomski anali , 52 (174-175), 28-44.

Kencana Petroleum Berhad. (2011). Annual Report 2011. KPB.

Kuprenas, J. A. (2003). Implementation and Performance of a Matrix Organization Structure. Internation Journal of Project Management , 21, 51-62.

Larson, E. W., \& Gobeli, D. H. (1987). Matrix Management: Contradictions and Insights. California Management Review , 29 (4), 126-138.

Mahmood, M. (2010). Strategy, Structure And HRM Practices In Multinational Subsidiaries: European Mncs In A Developing Country Context. 1-20.

Maleki, A. (2014). The Relationship Between Perception of Oranization Structure and Human Resource Development. International Journal of Asian Social Science, 585-597.

Mansueto, J. (2013). Morning Star Annual Report 2013.

Montana, P., \& Charnov, B. (1993). Organizational Structures: Concepts and Formats. Business Review Series, 155-169.

O, G., \& H, L. (2015). Service risk perception and risk management strategies in business to business tourism partnerships. Tourism Management Perspectives , 7-17.

Pilenko, T. (2012). Reference Document Including the Annual Financial Report. Grande Armee: Technip.

Simoes, V. C. (2006). Subsidiary Decision Making Autonomy: Competences, Integration And Local. 128.

Steensen, F. E. (2014). Five types of Organizational Strategy. Journal of Mnagement , 266-281.

Taggart, J., \& Neil, H. (1999). Determinants of Autonomy in Multinational Corporation Subsidiaries. European Management Journal , 226-236. 
Tohidi, H. (2011). The Role of Risk Management in IT Systems of Organizations. Procedia Computer Science, 881-887.

Wilhelm, T. (2013). Pentest Project Management. In P. P. Testing. Elsevier.

Wright, C. M., \& Mechling, G. (2002). The Importance of Operations Management Problems. Omega , 77-87. 